\title{
Oligogalacturonides: Novel Signaling Molecules in Rhizobium-Legume Communications
}

\author{
Roberto Moscatiello, ${ }^{1}$ Barbara Baldan, ${ }^{1}$ Andrea Squartini, ${ }^{2}$ Paola Mariani, ${ }^{1}$ and Lorella Navazio ${ }^{1}$ \\ ${ }^{1}$ Dipartimento di Biologia, Università di Padova, Via U. Bassi 58/B, 35131 Padova, Italy; '2Dipartimento di Biotecnologie Agrarie, \\ Università di Padova, Viale dell'Università 16, 35020 Legnaro, Padova, Italy
}

Submitted 16 March 2012. Accepted 8 July 2012.

\begin{abstract}
Oligogalacturonides are pectic fragments of the plant cell wall, whose signaling role has been described thus far during plant development and plant-pathogen interactions. In the present work, we evaluated the potential involvement of oligogalacturonides in the molecular communications between legumes and rhizobia during the establishment of nitrogen-fixing symbiosis. Oligogalacturonides with a degree of polymerization of 10 to 15 were found to trigger a rapid intracellular production of reactive oxygen species in Rhizobium leguminosarum bv. viciae 3841. Accumulation of $\mathrm{H}_{2} \mathrm{O}_{2}$, detected by both $2^{\prime}, 7^{\prime}$-dichlorodihydrofluorescein diacetate-based fluorescence and electron-dense deposits of cerium perhydroxides, was transient and did not affect bacterial cell viability, due to the prompt activation of the kat $G$ gene encoding a catalase. Calcium measurements carried out in $R$. leguminosarum transformed with the bioluminescent $\mathrm{Ca}^{2+}$ reporter aequorin demonstrated the induction of a rapid and remarkable intracellular $\mathrm{Ca}^{2+}$ increase in response to oligogalacturonides. When applied jointly with naringenin, oligogalacturonides effectively inhibited flavonoid-induced nod gene expression, indicating an antagonistic interplay between oligogalacturonides and inducing flavonoids in the early stages of plant root colonization. The above data suggest a novel role for oligogalacturonides as signaling molecules released in the rhizosphere in the initial rhizobium-legume interaction.
\end{abstract}

Oligogalacturonides (OG) are short linear molecules of $\alpha-1,4-$ D-galactopyranosyluronic acid residues (from 2 to approximately 20) released upon degradation of homogalacturonan from the plant primary cell wall (Ridley et al. 2001). They may be generated by the action of polygalacturonases and pectate lyases of either plant origin (e.g., during fruit ripening, leaf abscission, pollen tube growth, and pathogen attack) or microbial origin. In addition to plant pathogens, even beneficial microbes such as rhizobia produce pectinolytic enzymes (Angle 1986; Fauvart et al. 2009; Hubbell et al. 1978; Iannetta et al. 1997; Jimenez-Zurdo et al. 1996; Martinez-Molina et al. 1979; Mateos et al. 1992, 2001; Plazinski and Rolfe 1985; Wei et al. 2008). The localized digestion of the plant cell wall at the root hair tip by rhizobial cell-wall-degrading enzymes such as cellulases has been shown to represent a critical early step during plant root colonization by rhizobia (Robledo et al. 2008, 2011). Moreover, it has been recently demonstrated that legumes

Corresponding author: L. Navazio; E-mail: lorella.navazio@unipd.it

* The $e$-Xtra logo stands for "electronic extra" and indicates that two supplementary figures and one supplementary table are published online. themselves supply a Nod-factor-inducible pectate lyase, allowing for the penetration of rhizobia in the nascent infection thread (Xie et al. 2012). OG may also be generated from the high molecular weight polysaccharide mucilage released in the rhizosphere by means of the controlled detachment of border cells from the root cap (Hawes et al. 2003; Wen et al. 2007).

OG have long been known to play a signaling role in plants, by activating a $\mathrm{Ca}^{2+}$-mediated signaling pathway leading to the production of reactive oxygen species (ROS) (Lecourieux et al. 2002; Navazio et al. 2002) and activation of defense genes (Denoux et al. 2008; Moscatiello et al. 2006). OG also exert several morphogenetic effects on plants, mainly inhibition of auxin-induced processes (Altamura et al. 1998; Bellincampi et al. 1993, 1996, 2000) and enhancement of cytokinin-induced ones (Falasca et al. 2008). Furthermore, OG have been shown to modulate the pattern of somatic embryogenesis (Baldan et al. 2003).

In the present study, we have considered whether OG may be perceived by Rhizobium leguminosarum bv. viciae 3841 and carried out a dissection of the early steps of the signal transduction pathway activated by OG in rhizobia. The obtained results provide evidence for a novel signaling role played by these oligosaccharides during plant-rhizobium symbiotic interactions.

\section{RESULTS}

OG elicit intracellular ROS accumulation

in R. leguminosarum bv. viciae.

OG with a degree of polymerization (DP) of 10 to 15 were found to evoke a transient accumulation of ROS in R. leguminosarum bv. viciae 3841 when tested at a concentration range of 10 to $40 \mu \mathrm{g} / \mathrm{ml}$. Intracellular ROS production that was detected by means of $2^{\prime}, 7^{\prime}$-dichlorodihydrofluorescein diacetate $\left(\mathrm{H}_{2}\right.$ DCFDA)-based fluorescence started after approximately 5 min of bacterial incubation with OG and lasted for approximately 30 min (Fig. 1).

Accumulation of hydrogen peroxide $\left(\mathrm{H}_{2} \mathrm{O}_{2}\right)$ was confirmed by experiments of in situ cytochemical localization of $\mathrm{H}_{2} \mathrm{O}_{2}$, based on the generation of cerium perhydroxides after incubation with $\mathrm{CeCl}_{3}$. Whereas no $\mathrm{H}_{2} \mathrm{O}_{2}$ accumulation was observed in control rhizobial cells (Fig. 2A), electron-dense deposits of cerium perhydroxides were present in the periplasm (Fig. 2D) or on the surface of the outer membrane (Fig. 2E) at different time intervals from the beginning of OG treatment. The results show that $\mathrm{H}_{2} \mathrm{O}_{2}$ production is an early rhizobial response to OG: at 5 min after the beginning of the incubation with OG, very dense cerium deposits were visible (Fig. 2B), which became fainter and distributed as patches after $30 \mathrm{~min}$ (Fig. 2C). In both control and treated samples of $R$. leguminosarum bv. 
viciae, small electron-dense spherical compartments, commonly known as polyphosphate (volutin) granules and possibly identifiable as acidocalcisomes putatively involved in $\mathrm{Ca}^{2+}$ handling (Docampo and Moreno 2011), were often observed (Fig. 2).

\section{$\mathrm{Ca}^{2+}$-based perception of OG by $\mathrm{R}$. leguminosarum.}

To analyze the potential participation of calcium in the perception of OG by rhizobia, $R$. leguminosarum bv. viciae 3841 was transformed with the plasmid pAEQ80, encoding the bioluminescent $\mathrm{Ca}^{2+}$ reporter aequorin (Moscatiello et al. 2009). $\mathrm{Ca}^{2+}$ measurements carried out in $R$. leguminosarum upon challenge with $O G$ demonstrated the induction in rhizobia of transient elevations in the cytosolic concentration of $\mathrm{Ca}^{2+}$ $\left(\left[\mathrm{Ca}^{2+}\right]_{\text {cyt }}\right)$, whose amplitude was found to be dose dependent, until the saturating concentration of $40 \mu \mathrm{g} / \mathrm{ml}$ (corresponding to $18 \mu \mathrm{M}$ ) was reached (Fig. 3A). Aequorin-expressing $R$. le-
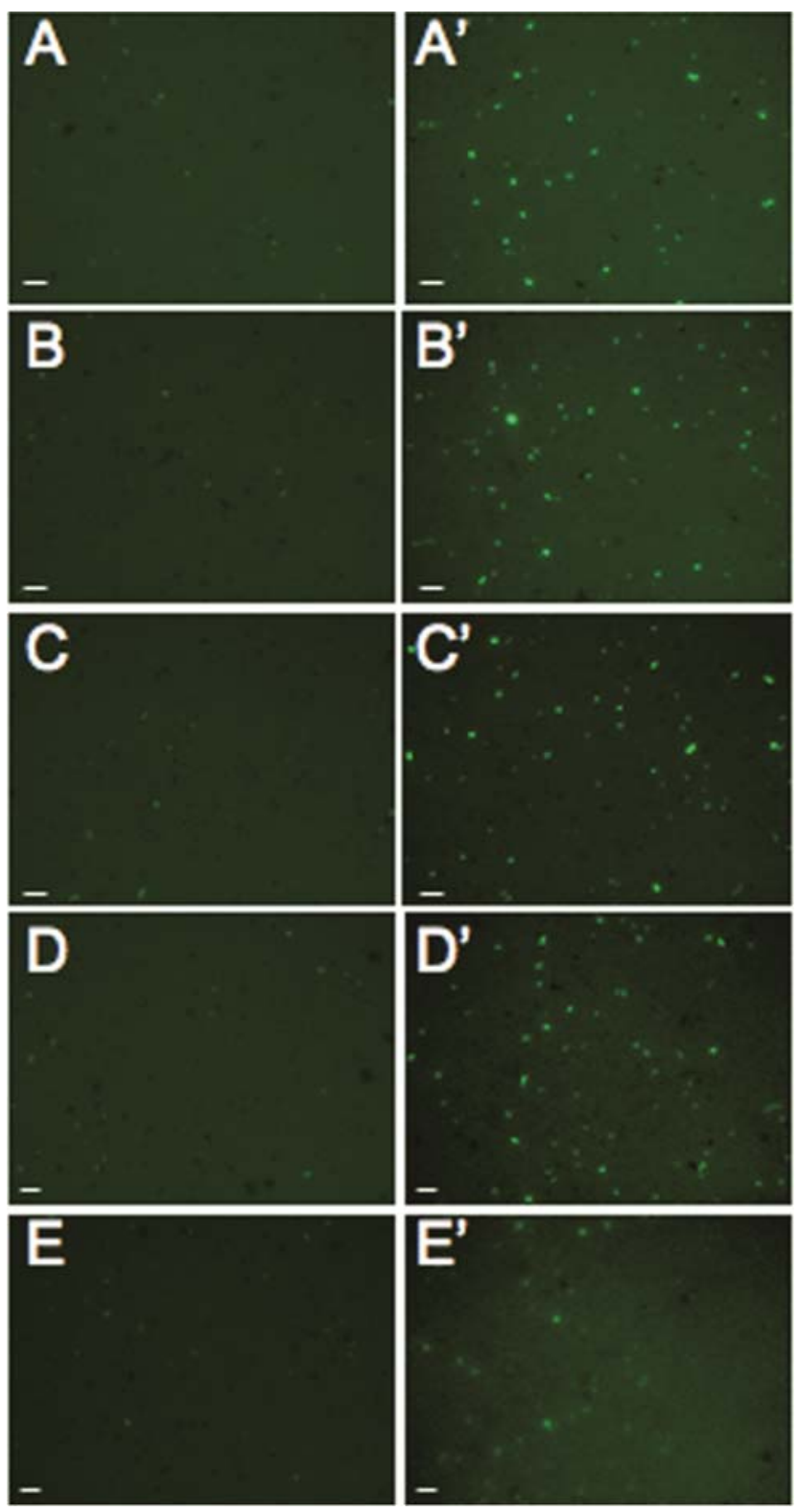

Fig. 1. Effect of oligogalacturonides (OG) on the production of reactive oxygen species (ROS) in Rhizobium leguminosarum bv. viciae 3841. ROS formation was detected by $2^{\prime}, 7^{\prime}$-dichlorodihydrofluorescein diacetate staining. Fluorescence microscopy images of bacterial cells incubated for different time intervals with $\mathbf{A}$ to $\mathbf{E}$, cell culture medium only (control); $\mathbf{A}^{\prime}$ to $\mathbf{E}^{\prime}, \mathrm{OG}$ at $40 \mu \mathrm{g} / \mathrm{ml}$ (treated samples). $\mathbf{A}$ and $\mathbf{A}^{\prime}, 5 \mathrm{~min} ; \mathbf{B}$ and $\mathbf{B}$ ', 10 min; C and C', $20 \mathrm{~min}$; $\mathbf{D}$ and D', $30 \mathrm{~min} ; \mathbf{E}$ and E', $35 \mathrm{~min}$. Bar: $10 \mu \mathrm{m}$. guminosarum 8401 that lacks its symbiotic plasmid was found to respond to OG with a similar behavior as strain 3841 , although with a higher sensitivity in terms of the magnitude of the triggered $\mathrm{Ca}^{2+}$ increase (Fig. 3B) and ROS production (data not shown), being the maximal response obtained with a much lower OG dose $(5 \mu \mathrm{g} / \mathrm{ml})$.

To check whether rhizobia may perceive the potential oxidative stress caused by $\mathrm{OG}$ in a $\mathrm{Ca}^{2+}$-dependent manner, cell cultures of $R$. leguminosarum transformed with aequorin were challenged with increasing concentrations of $\mathrm{H}_{2} \mathrm{O}_{2}$. Both strains 3841 and 8401 responded to 1 and $10 \mathrm{mM} \mathrm{H}_{2} \mathrm{O}_{2}$ with remarkable $\mathrm{Ca}^{2+}$ changes (Fig. $3 \mathrm{~A}$ and $\mathrm{B}$, insets), suggesting a potential dual involvement of $\mathrm{Ca}^{2+}$ (i.e., in the initial perception of $\mathrm{OG}$ and in the subsequent oxidative stress response).

\section{OG activate an ROS scavenging system and} counteract naringenin-induced nod gene expression.

Reverse-transcription polymerase chain reaction (RT-PCR) analyses of gene expression in $R$. leguminosarum bv. viciae 3841 showed no induction by OG $(40 \mu \mathrm{g} / \mathrm{ml}$ for $10 \mathrm{~min}, 30$ $\mathrm{min}$, or $1 \mathrm{~h}$ ) of the genes homologous to the cellulase-encoding gene celC2 of $R$. leguminosarum bv. trifolii (Robledo et al. 2008), and the picA and pgl loci of Agrobacterium tumefaciens (Rong et al. 1994), encoding putative polygalacturonase-like proteins (data not shown). A significant upregulation was detected for the kat G gene that has been previously shown to encode for the predominant catalase in both $R$. etli (Vargas et al. 2003) and Bradyrhizobium japonicum (Panek and O'Brian, 2004). The constitutive transcript level of katG was progressively enhanced during the first 30-min treatment of rhizobia with $\mathrm{OG}$ at $40 \mu \mathrm{g} / \mathrm{ml}$ (1.6-fold after $10 \mathrm{~min}$ and 2.3-fold after $30 \mathrm{~min}, P<0.05)$ before decreasing back to basal values after $1 \mathrm{~h}$ (Fig. 4).

In keeping with the activation of an efficient ROS scavenging system potentially involved in the dissipation of the OGinduced $\mathrm{H}_{2} \mathrm{O}_{2}$ production (see previous paragraph), bacterial cell viability was found not to be affected by OG treatment, as demonstrated by staining of rhizobia with SYTO 9 and propidium iodide after $1 \mathrm{~h}$ of incubation with the oligosaccharide elicitors (Fig. 5).

Treatment of rhizobia with OG $(40 \mu \mathrm{g} / \mathrm{ml}$ for $1 \mathrm{~h})$ did not induce the expression of nodC, an $\mathrm{N}$-acetylglucosaminyltransferase-encoding gene centrally involved in Nod-factor biosynthesis. When OG were administered to R. leguminosarum 3841 together with the flavonoid naringenin, the transcriptional activation of nodC induced by naringenin $(10 \mu \mathrm{M})$ was found to be effectively inhibited (Fig. 6A). A similar, although partial, antagonistic effect played by OG on the inducing activity of naringenin was obtained by using $R$. leguminosarum 8401 $\left(\mathrm{pSym}^{-}\right)$, containing the pIJ1477 plasmid (nodC-lacZ fusion), and the pIJ1518 plasmid, carrying the gene encoding for the transcriptional activator NodD, essential for the expression of the common nodulation (nod) genes (Fig. 6B), in Miller assays. In parallel experiments, it was verified that the treatment with OG did not have any effect on the bacterial culture growth for up to $8 \mathrm{~h}$ of incubation (data not shown). Considering that our exposure of exponentially growing cells to OG lasted for only $1 \mathrm{~h}$, such control ruled out the possibility that the lower expression level observed could be due to a general effect on cell growth rate.

In contrast, the constitutive expression of nodD was not altered by treatment with OG, administered either singly or in combination with naringenin, in both strain 3841 (Fig. 6A) and 8401 containing the pIJ1478 plasmid (nodD-lacZ fusion) (Fig. 6C). Likewise, no effect on nodD expression was observed in backgrounds also containing the full functional copy of the gene because the treatment of strain 8401 pIJ1478 
(nodD-lacZ) pIJ1518 (nodD) with either OG or OG + naringenin did not alter the negative autoregulation of the nodD gene (data not shown).

An OG preparation with a DP of 1 to 5, as well as the final product of $\mathrm{OG}$ degradation (i.e., the galacturonic acid monomer), could neither trigger $\left[\mathrm{Ca}^{2+}\right]_{\mathrm{cyt}}$ changes nor affect naringenin induction of nod genes (Supplementary Fig. S1), indicating that the DP size of the OG fractions is likely to play a crucial role in their bioactivity.

In agreement with the in vitro data about nod gene expression, Vicia sativa subsp. nigra roots treated with culture filtrates from $R$. leguminosarum bv. viciae 3841 cells, previously incubated overnight with OG of DP 10 to $15(40 \mu \mathrm{g} / \mathrm{ml})$ and naringenin $(10 \mu \mathrm{M})$, were found to lack the root hair deformations that were observed with culture filtrates from naringenin-induced rhizobia, suggesting the effective absence of Nod factors in supernatants of cultures in which naringenin was supplied along with OG (Supplementary Fig. S2).

\section{DISCUSSION}

Research on OG in the last two decades has been mainly focused on the effects of these plant cell-wall-derived oligosaccha- rides on plant growth and development and elicitation of plant defenses during plant-pathogen interactions. Different groups have demonstrated that $\mathrm{OG}$ activate transient cytosolic $\mathrm{Ca}^{2+}$ changes and an oxidative burst in plant cells (Lecourieux et al. 2002; Navazio et al. 2002). More recently, cDNA microarray analyses have uncovered the transcriptional activation by $\mathrm{OG}$ of genes involved in multiple defense signaling pathways: in particular, the mitogen-activated protein kinase gene family, genes involved in plant cell wall modification, jasmonic acid/ethyleneassociated processes, and several transcription factor-encoding genes (Denoux et al. 2008; Moscatiello et al. 2006). Recently, a role of the plant wall-associated kinase 1 (WAK1) as a receptor for OG has also been demonstrated (Brutus et al. 2010). It has to be noted that, from the plant point of view, OG should be considered as host-associated molecular patterns rather than pathogen-associated molecular pattern, because they do not derive from the pathogen but from the host plant cell (Galletti et al. 2009).

OG may be generated not only during the interactions of plants with pathogens but also with beneficial microbes such as rhizobia, by the localized action of pectinolytic enzymes of either microbial or plant origin (Ljunggren and Fahraeus 1959, 1961; Xie et al. 2012) during root infection by rhizobia. Nev-
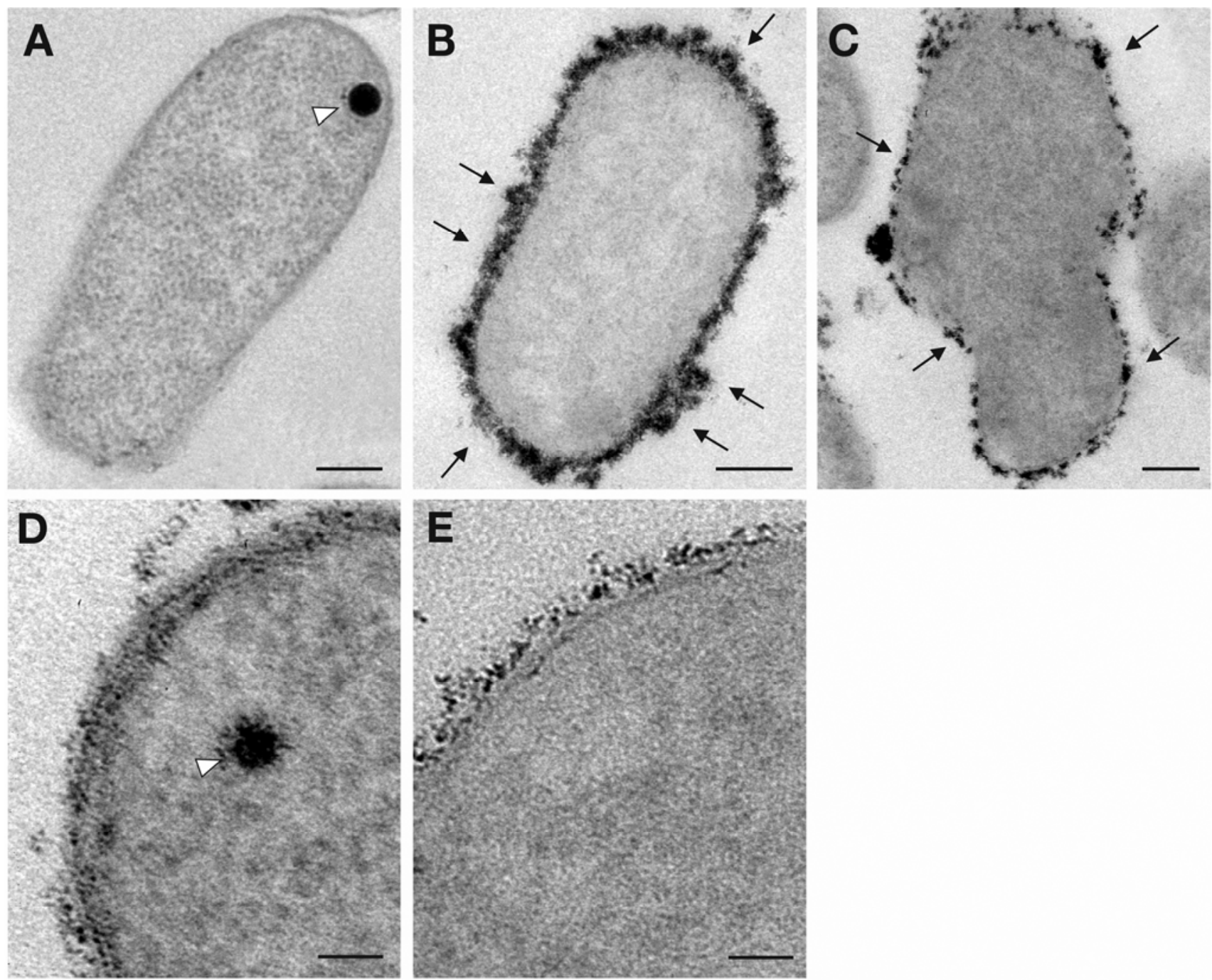

Fig. 2. Localization of $\mathrm{H}_{2} \mathrm{O}_{2}$ accumulation in Rhizobium leguminosarum bv. viciae 3841 in response to oligogalacturonides (OG). Electron micrographs of $\mathbf{A}$, control rhizobia and $\mathbf{B}$ and $\mathbf{C}$, bacteria treated with $\mathrm{OG}$ at $40 \mu \mathrm{g} / \mathrm{ml}$ for $\mathbf{B}, 5 \mathrm{~min}$ and $\mathbf{C}, 30 \mathrm{~min}$. At the end of treatment, samples were incubated with $\mathrm{CeCl}_{3}$ and processed for transmission electron microscopy (TEM). D and E, Higher-magnification TEM images of OG-treated rhizobia showing cerium perhydroxide precipitates in the periplasm or on the surface of the outer membrane. Arrows, electron-dense deposits of cerium perhydroxides. Arrowhead, acidocalcisome (polyphosphate/volutin) granules. Bar: A to C, $200 \mathrm{~nm}$; D and E, $50 \mathrm{~nm}$. 
ertheless, the potential role exerted by OG during beneficial plant-microbe interactions has not yet been evaluated.

In this work, OG with a DP of 10 to 15 were found to trigger an oxidative stress response in $R$. leguminosarum bv. viciae 3841 , given by a transient accumulation of ROS and the subsequent prompt activation of a catalase-based scavenging system. Interestingly, the occurrence of an oxidative burst at the site of attempted invasion seems to be a common trait in both pathogenic and symbiotic interactions (Nanda et al. 2010; Torres 2010). Indeed, ROS production by the plant host has been highlighted by several groups during the early stages of legumerhizobium interactions (Bueno et al. 2001; Cardenas et al. 2008; D'Haeze et al. 2003; Lohar et al. 2007; Peleg-Grossman et al. 2007; Ramu et al. 2002; Santos et al. 2001). Reviews on the production of ROS by legumes in the context of nodulation have been compiled (Glyan'ko and Vasil'eva 2010) and the mechanisms of their scavenging have been listed (Matamoros et al. 2003). Salzwedel and Dazzo (1993) demonstrated rhizobial species-dependent transient induction and localization of legume host root peroxidase at the site of incipient microsymbiont penetration and its role during successful primary host
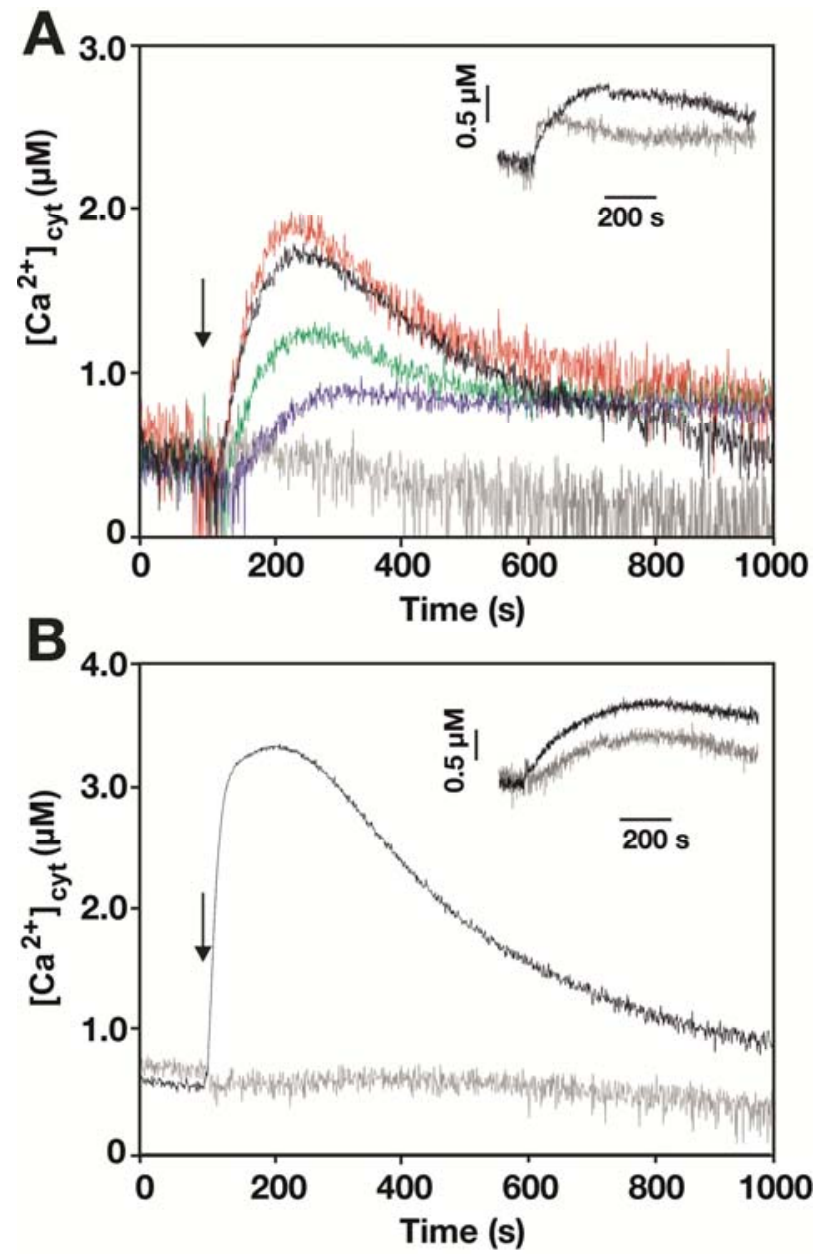

Fig. 3. Monitoring of cytosolic $\mathrm{Ca}^{2+}$ concentration $\left(\left[\mathrm{Ca}^{2+}\right]_{\text {cyt }}\right)$ in aequorinexpressing Rhizobium leguminosarum in response to oligogalacturonides (OG). OG were administered to A, R. leguminosarum 3841 (blue trace, 10 $\mu \mathrm{g} / \mathrm{ml}$; green trace, $25 \mu \mathrm{g} / \mathrm{ml}$; black trace, $40 \mu \mathrm{g} / \mathrm{ml}$; red trace, $50 \mu \mathrm{g} / \mathrm{ml}$ ); and B, R. leguminosarum 8401 (black trace, $5 \mu \mathrm{g} / \mathrm{ml}$ ). Rhizobia were treated with buffer for $\mathrm{Ca}^{2+}$ measurements as control (gray trace). The arrow indicates the time of injection $(100 \mathrm{~s})$. In the insets, the effect of oxidative stress on $\left[\mathrm{Ca}^{2+}\right]_{\text {cyt }}$ in $R$. leguminosarum is shown. Different doses of $\mathrm{H}_{2} \mathrm{O}_{2}$ (gray trace, $1 \mathrm{mM}$; black trace, $10 \mathrm{mM}$ ) were applied to aequorin-expressing $R$. leguminosarum A, inset, 3841 and $\mathbf{B}$, inset, 8401. $\mathrm{Ca}^{2+}$ traces are representative of three independent experiments which gave very similar results. infection. Moreover, a Sinorhizobium meliloti mutant overexpressing the housekeeping catalase KatB exhibited a delayed nodulation phenotype, suggesting that $\mathrm{H}_{2} \mathrm{O}_{2}$ is required for optimal progression of Medicago sativa infection (Jamet et al. 2007). ROS, far from being just toxic byproducts of aerobic metabolism, are increasingly being appreciated as central players in signaling networks from bacteria to eukaryotic cells (Mittler et al. 2011). The role of redox signals in establishing and maintaining symbiosis between rhizobia and legumes has been reviewed by Chang and associates (2009).

Our results, as regards OG-induced $\mathrm{H}_{2} \mathrm{O}_{2}$, have been obtained in vitro on rhizobia growing in TY medium; nevertheless, also under these ex planta conditions, rhizobia are known to be fully able to be induced by plant flavonoids and to produce, in return, their active Nod factors that can trigger nodulation. Because OG-producing pectate lyase has been demonstrated to act right at the onset of nodulation (Xie et al. 2012), it is possible to speculate that $\mathrm{H}_{2} \mathrm{O}_{2}$ may be produced during the early phases of rhizobium-legume interactions, as a result of the activation of not only the ROS-producing system of the plant host but also the symbiotic microorganism.

ROS are known to be formed in bacteria when $\mathrm{O}_{2}$ oxidizes redox enzymes involved in electron transfer to other substrates (Imlay 2003). Possible sources of endogenous $\mathrm{H}_{2} \mathrm{O}_{2}$ have recently been investigated in Escherichia coli (Korshunov and Imlay 2010).

To cope with OG-induced oxidative stress, $R$. leguminosarum cells were found to rapidly upregulate the catalase-encoding gene katG. The prompt induction of oxidative stress-related genes is a common mechanism of primary and secondary oxidative stress response in bacteria (Mols and Abee 2011).

Transformation of $R$. leguminosarum 3841 and 8401 with a plasmid encoding for the $\mathrm{Ca}^{2+}$-sensitive photoprotein aequorin allowed for the elucidation of the signaling pathway evoked by OG that was found to involve a potential twofold participation of calcium as intracellular messenger both upstream and downstream of the oxidative burst. The recombinant aequorin technique has been firmly demonstrated to be one of the most suitable methods to perform $\mathrm{Ca}^{2+}$ measurements in bacteria (Barrán-Berdón et al. 2011; Campbell et al. 2007). The $\mathrm{Ca}^{2+}$-based signaling mechanism underlying OG perception by $R$. leguminosarum bv. viciae extends the range of environmental stimuli that evoke transient $\mathrm{Ca}^{2+}$ changes in rhizobia (Moscatiello et al. 2009, 2010) and confirms the versatility and

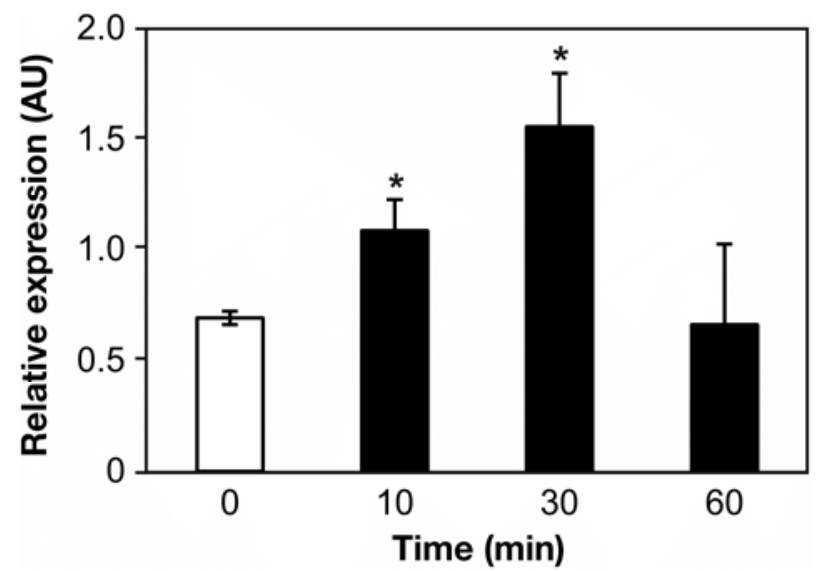

Fig. 4. Reverse-transcriptase polymerase chain reaction analysis of katG gene expression in Rhizobium leguminosarum bv. viciae 3841. Rhizobia were treated with oligogalacturonides (OG) $(40 \mu \mathrm{g} / \mathrm{ml})$ for different time intervals. Relative transcript abundance was normalized against $16 \mathrm{~S}$ rRNA. Data are the means \pm standard error of three independent experiments; * indicates statistically significant at $P<0.05$. 
potential universality of $\mathrm{Ca}^{2+}$ as a cellular regulator not only in eukaryotes (Cai and Clapham 2012; Clapham 2007; Dodd et al. 2010) but also in bacteria (Dominguez 2004; Stael et al. 2012). It is still unknown whether the extracellular medium represents the main source for $\mathrm{Ca}^{2+}$ fluxes in bacteria, or whether intracellular $\mathrm{Ca}^{2+}$ stores such as the so-called acidocalcisomes (Docampo and Moreno 2011) may also be involved in $\mathrm{Ca}^{2+}$ handling. Indeed, it has been shown that $\mathrm{Ca}^{2+}$ may be mobilized from the periplasmic space in E. coli (Jones et al. 2002) and from still unidentified intracellular $\mathrm{Ca}^{2+}$ stores in cyanobacteria (Torrecilla et al. 2004).

Our data shed light on a previously uninvestigated involvement of OG in the molecular communications underlying plantrhizobium symbiotic interactions (Murray 2011; Oldroyd et al. 2011). On the basis of our results, we propose a new signaling role for these long-standing molecular signals: they are perceived and transduced not only by plants but also by rhizobia, with a similar DP size and concentration range required for their biological activity. It has to be noted that OG seem to be the only informational chemicals known to date to be sensed by both partners of the nitrogen-fixing symbiosis. Interestingly, in both the plant host and the microsymbiont, $\mathrm{OG}$ activate a $\mathrm{Ca}^{2+}$ mediated signaling pathway and a transient oxidative burst.

Other oligosaccharide elicitors (i.e., oligoguluronates and oligomannuronates) have recently been shown to trigger transient $\left[\mathrm{Ca}^{2+}\right]_{\text {cyt }}$ increases in both gram-negative and gram-posi- tive bacteria such as E. coli and Bacillus subtilis. The observed increased intracellular $\mathrm{Ca}^{2+}$ levels have been hypothesized to contribute to the enhancement of secondary metabolite levels in microbes (Murphy et al. 2011). It remains to be ascertained whether elicitation with OG may lead to the accumulation of some secondary metabolites in rhizobia.

Interestingly, we found that OG effectively blocked the activation of naringenin-inducible nod genes, lending themselves as novel potential anti-inducers in R. leguminosarum, in addition to the well-known noninducing flavonoids in this species such as genistein and daidzein. The level of transcription inhibition observed by RT-PCR in strain 3841 was total, whereas that assayed at post-translational level by Miller assay in 8401 $\left(\mathrm{pSym}^{-}\right)$containing $\mathrm{pIJ} 1477$ and $\mathrm{pIJ} 1518$ was partial. This can be explained by the fact that the latter construct bears the nod genes in plasmids whose copy number is higher than that of the pSym in wild-type 3841. Moreover, the occurrence of basal levels of expressed proteins constitutes a common trait in bacterial phenotypic assays when compared with the stringency of transcriptional regulation events.

The lack of any detectable effect by OG on nodD expression (in both 3841 and 8401 pIJ1478) suggests that the action is played on genuine flavonoid-inducible genes, because the constitutively expressed nodD is not affected. Moreover, because NodD is also known to negatively regulate the expression of its own gene, the fact that, in a nodD ${ }^{+}$background (8401
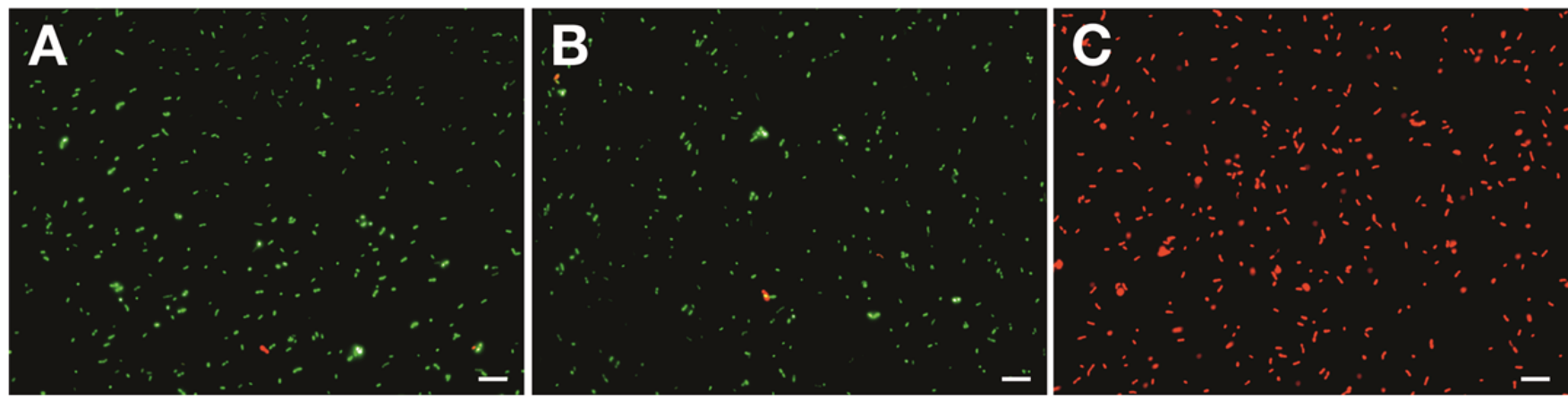

Fig. 5. Viability of Rhizobium leguminosarum bv. viciae 3841 after treatment with oligogalacturonides (OG). Bacterial cell viability was monitored with the LIVE/DEAD BacLight Bacterial Viability kit, consisting in a mixture of the nucleic acid stains SYTO 9 and propidium iodide. Mid-exponential-phase bacterial cells were treated for $1 \mathrm{~h}$ in A, control conditions; B, OG at $40 \mu \mathrm{g} / \mathrm{ml}$; or C, $70 \%$ isopropyl alcohol. Merged images of SYTO 9 and propidium iodide fluorescence are shown. Bar, $10 \mu \mathrm{m}$.
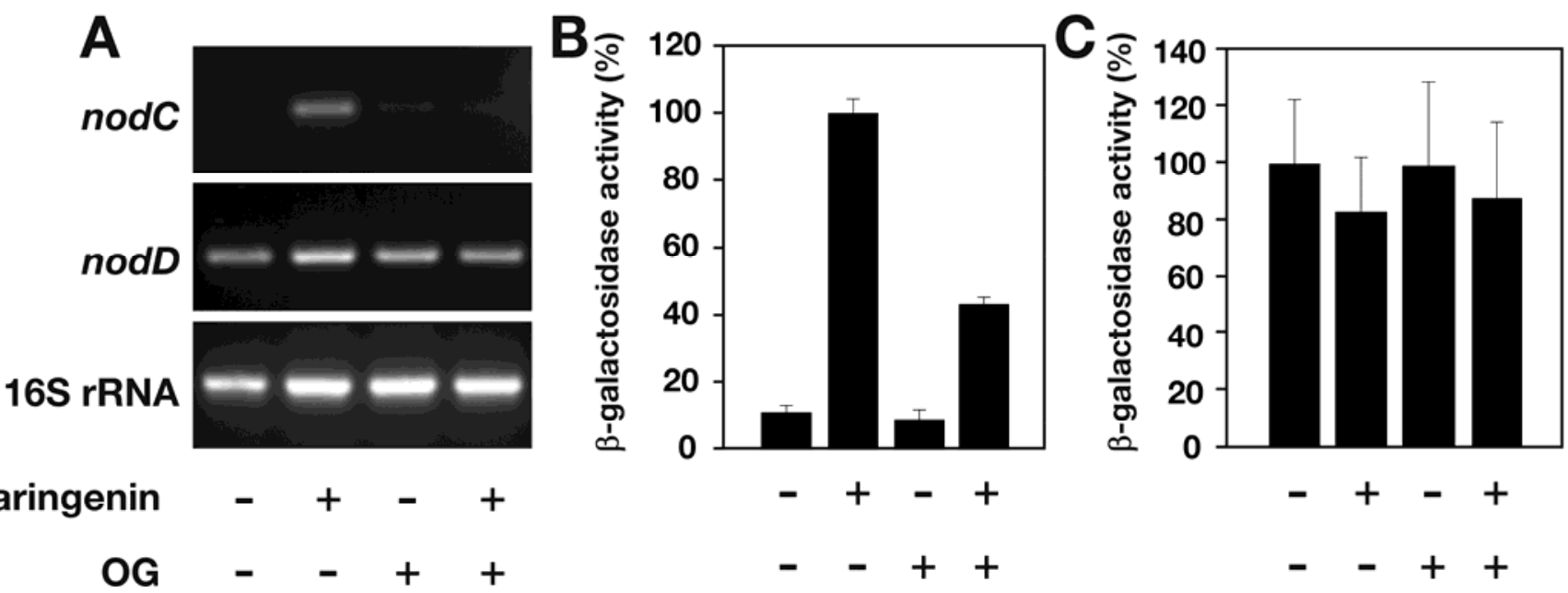

Fig. 6. Analysis of nodC and nodD gene expression in Rhizobium leguminosarum. Induction of nodulation genes was analyzed by A, reverse-transcriptase polymerase chain reaction in $R$. leguminosarum 3841 and $\mathbf{B}, \beta$-galactosidase activity in $R$. leguminosarum 8401 containing plasmids pIJ1477 (nodC-lacZ fusion) and pIJ1518 (nodD) or C, pIJ1478 (nodD-lacZ fusion). Rhizobia were incubated for A, $1 \mathrm{~h}$ or $\mathbf{B}$ and $\mathbf{C}, 4 \mathrm{~h}$ with culture medium only, OG (A, at 40 $\mu \mathrm{g} / \mathrm{ml}$ or $\mathbf{B}$ and $\mathbf{C}$, at $5 \mu \mathrm{g} / \mathrm{ml})$, naringenin $(10 \mu \mathrm{M})$, or the two treatments combined, as indicated. In A, transcription levels of 16S rRNA were used as standards. 
pIJ1478 pIJ1518), nodD transcription is not enhanced either suggests that the OG effect is not exerted via an interaction with the NodD protein or that, if this occurs, it does not impair its autoregulatory domain.

The finding that even the $8401\left(\mathrm{pSym}^{-}\right)$mutant strain of $R$. leguminosarum $\left(\mathrm{pSym}^{-}\right)$responds to $\mathrm{OG}$ with a transient $\mathrm{Ca}^{2+}$ change indicates that the OG receptor-encoding gene is not on the symbiotic plasmid. The molecular identity of such a receptor remains unknown, because database searches in the sequenced genome of $R$. leguminosarum 3841 (Young et al. 2006) did not reveal any genes homologous to plant WAK (data not shown), one isoform of which has recently been identified as encoding the OG receptor in plants (Brutus et al. 2010).

Hypothesizing on the possible reasons for a regulatory role of OG on nodulation genes, the naringenin-counteracting action played by OG may fulfill a modulatory role on nod gene expression along plant root invasion. During the infection thread progression throughout the root cortex, a localized degradation of the plant cell wall is repeated at each cell junction (Oldroyd et al. 2011), thereby providing multiple potential sites for OG generation. At each of these events, a tune-down of the nod genes might ensure a fine modulation of the Nod factor signal concentrations to the benefit of a minimal level of impact in the use of the specific entry tools, which is deemed appropriate for the compatible invasion of the homologous host legume.

To further dissect the complex $\mathrm{Ca}^{2+}$-mediated signaling cascades triggered by flavonoids (Moscatiello et al. 2010) and OG (this article) and their potential interplay, future investigations should be addressed to unraveling components of the $\mathrm{Ca}^{2+}$ signature decoding machinery in bacteria, in particular $\mathrm{Ca}^{2+}$ sensors and their targets (Michiels et al. 2002; Rigden et al. 2003, 2011; Zhou et al. 2006).

In this work, we have shown a previously underestimated role of $\mathrm{OG}$ as host-derived signals that may be sensed by rhizobia in a $\mathrm{Ca}^{2+}$-dependent manner and activate in the microsymbiont a transient production of $\mathrm{H}_{2} \mathrm{O}_{2}$. It is becoming increasingly evident that common themes underlie the molecular dialogue of plants with pathogenic and mutualistic microorganisms, which often makes use of similar molecular components and signaling processes (Gough and Cullimore 2011; Oldroyd and Robatzek 2011). A transient state of alert in which the two interacting partners have to reciprocally recognize themselves as friends and not foes may be essential for an optimal establishment of the symbiotic association. It is interesting to remark that, in pathogens, the invader is the one whose activity would generate OG and trigger plant defense responses whereas, in symbionts, their Nod factors would induce the plant to make its own pectate lyase (Xie et al. 2012) that could bring about OG which, in turn, would tune down the Nod factor production.

\section{MATERIALS AND METHODS}

\section{Chemicals.}

OG with a DP of 10 to 15 were produced and isolated as described by Moscatiello and associates (2006). OG with a DP of 1 to 5 were provided by D. Bellincampi (Rome). Coelenterazine was purchased from Invitrogen (Carlsbad, CA, U.S.A.). Molecular biology reagents were purchased from Promega Corp. (Madison, WI, U.S.A.), Qiagen (Hilden, Germany), and Clontech (Mountain View, CA, U.S.A.). The flavonoid naringenin and all other reagents were obtained from Sigma-Aldrich (St. Louis).

\section{Bacterial strains, plasmids, and culture conditions.}

$R$. leguminosarum bv. viciae 3841 was provided by P. Young (York, U.K.). R. leguminosarum 8401 that lacks the Sym plas- mid and carries the pIJ1477 plasmid (nodC-lacZ fusion) and pIJ1518 (cloned nodD), pIJ1478 (nodD-lacZ fusion), or pAEQ80 (cloned aequorin) (Moscatiello et al. 2010) were also used. Strains were grown in TY medium, containing the appropriate antibiotics (streptomycin at $500 \mu \mathrm{g} / \mathrm{ml}$ for strain 3841, tetracycline at $2 \mu \mathrm{g} / \mathrm{ml}$ for strain $8401 \mathrm{pIJ} 1477$ and $8401 \mathrm{pIJ} 1478$, and kanamycin at $50 \mu \mathrm{g} / \mathrm{ml}$ for strains containing pIJ1518 or pAEQ80 plasmids) at $28^{\circ} \mathrm{C}$ under shaking at $170^{\circ} \mathrm{C}$.

\section{Plant material.}

Seeds of $V$. sativa subsp. nigra (Vergerio Mangimi s.r.l., Padova, Italy) were surface sterilized by immersion in $\mathrm{H}_{2} \mathrm{SO}_{4}$ (4 min) followed by five washes in $\mathrm{H}_{2} \mathrm{O}(30 \mathrm{~min}), 3 \% \mathrm{NaClO}$ (4 min), and five washes in $\mathrm{H}_{2} \mathrm{O}$ (30 $\mathrm{min}$ ), and allowed to germinate for 3 days on $0.7 \%$ water agar at $24^{\circ} \mathrm{C}$ in the dark. Seedlings were transferred on $0.1 \%$ Jensen medium solidified with $1 \%$ agar, and $20 \mu \mathrm{l}$ of culture filtrates (through $0.20-\mu \mathrm{m}$ sterile filters) from $R$. leguminosarum bv. viciae 3841 cell suspensions that had previously been subjected to different overnight treatments were applied onto the roots. A sterile glass coverslip (12 $\mathrm{mm}$ in diameter) was placed on the root over the applied drop. Root hair observations were carried out after 12 $\mathrm{h}$ with a Leica DMI4000 B inverted microscope.

\section{Transformation of $R$. leguminosarum.}

The expression vector pAEQ80 carrying the apoaequorin cDNA under the control of the strong isopropyl $\beta$-D-thiogalactopyranoside (IPTG)-inducible synthetic promoter $\mathrm{P}_{\text {syn }}$ and conferring resistance to kanamycin (Moscatiello et al. 2009) was introduced into the $R$. leguminosarum bv. viciae 3841 using a freeze-thaw method (Vincze and Bowra 2006).

\section{Detection of ROS.}

Intracellular ROS production was detected as described by Maxwell and associates (1999). Exponentially growing cultures of $R$. leguminosarum (optical density at $600 \mathrm{~nm}\left[\mathrm{OD}_{600}\right]$ of approximately 0.25 ) were loaded with $10 \mu \mathrm{M} \mathrm{H}_{2}$ DCFDA (Invitrogen) for $30 \mathrm{~min}$. This nonpolar compound passively diffuses into cells where it is converted by endogenous esterases in $2^{\prime}, 7^{\prime}$-dichlorodihydrofluorescein, a nonfluorescent derivative that is rapidly oxidized to the highly fluorescent $2^{\prime}, 7^{\prime}$ dichlorofluorescein by intracellular peroxides. Excess dye was removed by extensive washing with fresh culture medium. Bacteria were treated with OG or cell culture medium only (control) and observed under a Leica DM5000 B fluorescence microscope, with excitation at 450 to $490 \mathrm{~nm}$ and emission at 500 to $550 \mathrm{~nm}$. Images were acquired with a Leica DFC $425 \mathrm{C}$ digital camera using the Leica Application Suite software.

\section{Cytochemical localization of $\mathrm{H}_{2} \mathrm{O}_{2}$.}

Cytochemical localization of $\mathrm{H}_{2} \mathrm{O}_{2}$ based on the generation of cerium perhydroxides was carried out as described by Bestwick and associates (1997). Briefly, mid-exponential-phase $R$. leguminosarum cells were treated with OG $(40 \mu \mathrm{g} / \mathrm{ml})$ for different time intervals or with cell culture medium only (control). After centrifugation, the bacterial pellet was incubated for $1 \mathrm{~h}$ in $5 \mathrm{mM} \mathrm{CeCl} \mathrm{Cl}_{3}$ and $50 \mathrm{mM} 3$-(N-morpholino)propanesulfonic acid, $\mathrm{pH}$ 7.2. The resedimented rhizobia were immediately fixed for $1 \mathrm{~h}$ in $1.25 \%$ ( $\mathrm{vol} / \mathrm{vol})$ glutaraldehyde/1.25\% (vol/vol) paraformaldehyde in $50 \mathrm{mM}$ sodium cacodylate $(\mathrm{CAB})$ buffer, $\mathrm{pH}$ 7.2. After two washes for 10 min in $\mathrm{CAB}$ buffer, cells were postfixed for $45 \mathrm{~min}$ in $1 \%$ (vol/vol) osmium tetroxide in $\mathrm{CAB}$ and washed as above. Dehydration was performed in a graded ethanol series. Samples were then transferred into propylene oxide and progressively embedded in Epon. Thin sections were obtained on a Reichert-Ultracut microtome, mounted on uncoated copper 
grids, and observed using a Tecnai 12-BT transmission electron microscope (FEI, Eindhoven, The Netherlands) operating at $120 \mathrm{kV}$ equipped with a Tietz camera.

\section{$\mathrm{Ca}^{2+}$ measurement assays with recombinant aequorin.}

Aequorin expression was induced by inoculating a loopful of pAEQ80-containing $R$. leguminosarum strains into $30 \mathrm{ml}$ of TY medium supplemented with the appropriate antibiotics and $1 \mathrm{mM}$ IPTG overnight, until an $\mathrm{OD}_{600}=0.25$ (corresponding to early exponential phase) was reached. Bacterial suspensions were washed and resuspended in buffer A (25 mM Hepes, 125 $\mathrm{mM} \mathrm{NaCl}$, and $\left.1 \mathrm{mM} \mathrm{MgCL}_{2}, \mathrm{pH} 7.5\right)$ and incubated with $5 \mu \mathrm{M}$ coelenterazine for $90 \mathrm{~min}$, as described by Campbell and associates (2007). Aequorin-based $\mathrm{Ca}^{2+}$ measurements were carried out in the presence of $6 \mathrm{mM} \mathrm{CaCl}_{2}$ (the same concentration as in TY medium) in a purpose-built luminometer (Electron Tubes Limited, Uxbridge, U.K.) as previously described (Moscatiello et al. 2010).

\section{Semiquantitative RT-PCR analysis.}

Extraction of RNA and RT-PCR analysis of gene expression were carried out as previously described (Moscatiello et al. 2009). Briefly, cells were grown to an $\mathrm{OD}_{600}$ of approximately 0.25 and subjected to the different treatments. After adding RNAprotect Bacteria Reagent (Qiagen), cells $\left(5 \times 10^{8}\right)$ were lysed with lysozyme (Sigma) at $0.5 \mathrm{mg} / \mathrm{ml}$ for $5 \mathrm{~min}$. RNA was isolated with RNeasy mini kit (Qiagen) according to the manufacturer's instructions, treated with DNase I (Promega Corp.), and quantified. cDNA was synthesized from $5 \mu \mathrm{g}$ of RNA using Random Decamers (Ambion) and SMARTScribe Reverse Transcriptase (Clontech) and diluted 1:5. First-strand cDNA (5 $\mu \mathrm{l})$ was used as a template for subsequent PCR analyses with Advantage 2 Polymerase mix (Clontech). The oligonucleotide primers used in this study (Supplementary Table S1) were designed against nodC, $k a t G$, and the gene sequences homologous to celC2 of R. leguminosarum bv. trifolii (Robledo et al. 2008), and picA and $\mathrm{pgl}$ of $A$. tumefaciens in the sequenced genome of $R$. leguminosarum bv. viciae 3841 (Young et al. 2006). To amplify the $16 \mathrm{~S}$ ribosomal RNA (rRNA) gene, Y1 and Y2 primers were used (Young et al. 1991). RT-PCR experiments were conducted in duplicate on three independent experiments. The statistical significance of differences between means was evaluated by the Student's $t$ test.

\section{$\boldsymbol{\beta}$-Galactosidase assay.}

R. leguminosarum 8401 pIJ1477 pIJ1518, containing both a nodC-lacZ gene fusion and a cloned nodD, and 8401 pIJ1478, containing a nodD-lac $Z$ gene fusion, were grown for $4 \mathrm{~h}$ in control conditions or with the specified compounds. The $\beta$-galactosidase activity assay was carried out as described by Miller (1972).

\section{Bacterial cell viability assay.}

Bacterial cell viability was monitored by the LIVE/DEAD BacLight bacterial viability kit (Invitrogen). This fluorescencebased assay utilizes a mixture of the nucleic acid stains SYTO 9 and propidium iodide to distinguish live and dead bacteria. The excitation and emission maxima are 480 and $500 \mathrm{~nm}$, respectively, for SYTO 9 and 490 and $635 \mathrm{~nm}$, respectively, for propidium iodide. Live bacteria fluoresce green, whereas dead bacteria fluoresce red. As a positive killing control, rhizobia were treated with $70 \%$ isopropyl alcohol (100\% dead bacteria).

\section{ACKNOWLEDGMENTS}

This work was supported by Programmi di Ricerca Scientifica di Rilevante Interesse Nazionale (2008WKPAWW to L. Navazio) and Ricerca
Scientifica quota EX-60\% (60A06-2248/11 to L. Navazio and 60A062448/11 to B. Baldan). We thank P. Young (York, U.K.) for kindly providing $R$. leguminosarum 3841, A. Downie (Norwich, U.K.) for $R$. leguminosarum 8401-based strains, and D. Bellincampi (Rome) for the short-sized OG.

\section{LITERATURE CITED}

Altamura, M. M., Zaghi, D., Salvi, G., De Lorenzo, G., and Bellincampi, D. 1998. Oligogalacturonides stimulate pericycle cell wall thickening and cell divisions leading to stoma formation in tobacco leaf explants. Planta 204:429-436.

Angle, J. S. 1986. Pectic and proteolytic enzymes produced by fast- and slow-growing soybean rhizobia. Soil Biol. Biochem. 18:115-116.

Baldan, B., Bertoldo, A., Navazio, L., and Mariani, P. 2003. Oligogalacturonide-induced changes in the developmental pattern of Daucus carota L. somatic embryos. Plant Sci. 165:337-348.

Barrán-Berdón, A. L., Rodea-Palomares, I., Leganés, F., and FernándezPiñas, F. 2011. Free $\mathrm{Ca}^{2+}$ as an early intracellular biomarker of exposure of cyanobacteria to environmental pollution. Anal. Bioanal. Chem. 400:1015-1029.

Bellincampi, D., Salvi, G., De Lorenzo, G., Cervone, F., Marfa, V., Eberhard, S., Darvill, A., and Albersheim, P. 1993. Oligogalacturonides inhibit the formation of roots on tobacco explants. Plant J. 4:207-213.

Bellincampi, D., Cardarelli, M., Zaghi, D., Serino, G., Salvi, G., Gatz, C., Cervone, F., Altamura, M. M., Costantino, P., and De Lorenzo, G. 1996. Oligogalacturonides prevent rhizogenesis in rolB-transformed tobacco explants by inhibiting auxin-induced expression of the rolB gene. Plant Cell 8:477-487.

Bellincampi, D., Dipierro, N., Salvi, G., Cervone, F., and De Lorenzo, G. 2000. Extracellular $\mathrm{H}_{2} \mathrm{O}_{2}$ induced by oligogalacturonides is not involved in the inhibition of the auxin-regulated $\mathrm{rolB}$ gene expression in tobacco leaf explants. Plant Physiol. 122:1379-1385.

Bestwick, C. S., Brown, I. R., Bennett, M. H., and Mansfield, J. W. 1997. Localization of hydrogen peroxide accumulation during the hypersensitive reaction of lettuce cells to Pseudomonas syringae pv. phaseolicola. Plant Cell 9:209-221.

Brutus, A., Sicilia, F., Macone, A., Cervone, F., and De Lorenzo, G. 2010. A domain swap approach reveals a role of the plant wall-associated kinase 1 (WAK1) as a receptor of oligogalacturonides. Proc. Natl. Acad. Sci. U.S.A. 107:9452-9457.

Bueno, P., Soto, M. J., Rodriguez-Rosales, M. P., Sanjuan, J., Olivares J, and Donaire, J. P. 2001. Time-course of lipoxygenase, antioxidant enzyme activities and $\mathrm{H}_{2} \mathrm{O}_{2}$ accumulation during early stages of Rhizobium legume symbiosis. New Phytol. 152:91-96.

Cai, X., and Clapham, D. E. 2012. Ancestral $\mathrm{Ca}^{2+}$ signaling machinery in early animal and fungal evolution. Mol. Biol. Evol. 29:91-100.

Campbell, A. K., Naseem, R., Wann, K. T., Holland, I. B., and Matthews, S. B. 2007. Fermentation product butane 2,3-diol induces $\mathrm{Ca}^{2+}$ transients in $E$. coli through activation of lanthanum-sensitive $\mathrm{Ca}^{2+}$ channels. Cell Calcium 41:97-106.

Cardenas, L., Martinez, A., Sanchez, F., and Quinto, C. 2008. Fast, transient and specific intracellular ROS changes in living root hair cells responding to Nod factors (NFs). Plant J. 56:802-813.

Chang, C., Damiani, I., Puppo, A., and Frendo, P. 2009. Redox changes during the legume-rhizobium symbiosis. Mol. Plant 2:370-377.

Clapham, D. E. 2007. Calcium signaling. Cell 131:1047-1058.

Denoux, C., Galletti, R., Mammarella, N., Gopalan, S., Werck, D., De Lorenzo, G., Ferrari, S., Ausubel, F. M., and Dewdney, J. 2008. Activation of defense response pathways by OGs and Flg22 elicitors in Arabidopsis seedlings. Mol. Plant 1:423-445.

D'Haeze, W., De Rycke, R., Mathis, R., Goormachtig, S., Pagnotta, S., Verplancke, C., Capoen, W., and Holsters, M. 2003. Reactive oxygen species and ethylene play a positive role in lateral root base nodulation of a semiaquatic legume. Proc. Natl. Acad. Sci. U.S.A. 100:1178911794.

Docampo, R., and Moreno, S. N. J. 2011. Acidocalcisomes. Cell Calcium 50:113-119.

Dodd, A. N., Kudla, J., and Sanders, D. 2010. The language of calcium signaling. Annu. Rev. Plant Biol. 61:593-620

Dominguez, D. C. 2004. Calcium signalling in bacteria. Mol. Microbiol. 54:291-297

Falasca, G., Capitani, F., Della Rovere, F., Zaghi, D., Franchin, C., Biondi, S., and Altamura, M. M. 2008. Oligogalacturonides enhance cytokinininduced vegetative shoot formation in tobacco explants, inhibit polyamine biosynthetic gene expression, and promote long-term remobilisation of cell calcium. Planta 227:835-852.

Fauvart, M., Verstraeten, N., Dombrecht, B., Venmans, R., Beullens, S., Heusdens, C., and Michiels, J. 2009. Rhizobium etli HrpW is a pectin- 
degrading enzyme and differs from phytopathogenic homologues in enzymically crucial tryptophan and glycine residues. Microbiology 155:3045-3054.

Galletti, R., De Lorenzo, G., and Ferrari, S. 2009. Host-derived signals activate plant innate immunity. Plant Signal. Behav. 4:33-34.

Glyan'ko, A. K., and Vasil'eva, G. G. 2010. Reactive oxygen and nitrogen species in legume-rhizobial symbiosis: A review. Appl. Biochem. Microbiol. 46:15-22.

Gough, C., and Cullimore, J. 2011. Lipo-chitooligosaccharide signaling in endosymbiotic plant-microbe interactions. Mol. Plant-Microbe Interact. 24:867-78.

Hawes, M. C., Bengough, G., Cassab, G., and Ponce, G. 2003. Root caps and rhizosphere. J. Plant Growth Regul. 21:352-367.

Hubbell, D. H., Morales, V. M., and Umali-Garcia, M. 1978. Pectolytic enzymes in Rhizobium. Appl. Environ. Microbiol. 35:210-213.

Iannetta, P., McMillan, G., and Sprent, J. I. 1997. Plant cell wall-degrading enzymes of Rhizobium leguminosarum bv. viciae: Their role in avoiding the host-plant defense response. Soil Biol. Biochem. 29:1019-1021.

Imlay, J. A. 2003. Pathways of oxidative damage. Annu. Rev. Microbiol. 57:395-418.

Jamet, A., Mandon, K., Puppo, A., and Hérouart, D. 2007. $\mathrm{H}_{2} \mathrm{O}_{2}$ is required for optimal establishment of the Medicago sativa/Sinorhizobium meliloti symbiosis. J. Bacteriol. 189:8741-8745.

Jiménez-Zurdo, J. I., Mateos, P. F., Dazzo, F. B., and Martinez-Molina, E. 1996. Cell-bound cellulase and polygalacturonase production by Rhizobium and Bradyrhizobium species. Soil Biol. Biochem. 28:917-921.

Jones, H., Holland, I. B., and Campbell, A. K. 2002. Direct measurement of free $\mathrm{Ca}^{2+}$ shows different regulation of $\mathrm{Ca}^{2+}$ between the periplasm and the cytosol of Escherichia coli. Cell Calcium 32:183-192.

Korshunov, S., and Imlay, J. A. 2010. Two sources of endogenous hydrogen peroxide in Escherichia coli. Mol. Microbiol. 75:1389-1401.

Lecourieux, D., Mazars, C., Pauly, N., Ranjeva, R., and Pugin, A. 2002. Analysis and effects of cytosolic free calcium increases in response to elicitors in Nicotiana plumbaginifolia cells. Plant Cell 14:2627-2641.

Ljunggren, H., and Fahraeus, G. 1959. Effect of Rhizobium polysaccharide on the formation of polygalacturonase in lucerne and clover. Nature 184:1578-1579.

Ljunggren, H., and Fahraeus, G. 1961. The role of polygalacturonase in root-hair invasion by nodule bacteria. J. Gen. Microbiol. 26:521-528

Lohar, D. P., Haridas, S., Gantt, J. S., and VandenBosch, K. A. 2007. A transient decrease in reactive oxygen species in roots leads to root hair deformation in the legume-rhizobia symbiosis. New Phytol. 173:39-49.

Martinez-Molina, E., Morales, V. M., and Hubbell, D. H. 1979. Hydrolytic enzyme production by Rhizobium. Appl. Environ. Microbiol. 38:11861188.

Matamoros, M. A., Dalton, D. A., Clemente, M. R., Rubio, M. C., Ramos, J., and Becana, M. 2003. Biochemistry and molecular biology of antioxidants in the rhizobia-legume symbiosis. Plant Physiol. 133:499-509.

Mateos, P. F., Jimenez-Zurdo, J. I., Chen, J., Squartini, A., Haack, S. K., Martinez-Molina, E., Hubbell, D. H., and Dazzo, F. B. 1992. Cell-associated pectinolytic and cellulolytic enzymes in Rhizobium leguminosarum biovar trifolii. Appl. Environ. Microbiol. 58:1816-1822.

Mateos, P. F., Baker, D. L., Petersen, M., Velázquez, E., Jiménez-Zurdo, J. I., Martínez-Molina, E., Squartini, A., Orgambide, G., Hubbell, D. H., and Dazzo, F. B. 2001. Erosion of root epidermal cell walls by Rhizobium polysaccharide-degrading enzymes as related to primary host infection in the Rhizobium-legume symbiosis. Can. J. Microbiol. 47:475487.

Maxwell, D. P., Wang, Y., and McIntosh, L. 1999. The alternative oxidase lowers mitochondrial reactive oxygen production in plant cells. Proc. Natl. Acad. Sci. U.S.A. 96:8271-8276.

Michiels, J., Xi, C., Verhaert, J., and Vanderleyden, J. 2002. The functions of $\mathrm{Ca}^{2+}$ in bacteria: A role for EF-hand proteins? Trends Microbiol. 10:87-93.

Miller, J. H. 1972. Pages 352-355 in: Experiments in Molecular Genetics. Cold Spring Harbor Laboratory Press, Cold Spring Harbor, NY, U.S.A.

Mittler, R., Vanderauwera, S., Suzuki, N., Miller, G., Tognetti, V. B., Vandepoele, K., Gollery, M., Shulaev, V., and Van Breusegem, F. 2011. ROS signaling: The new wave? Trends Plant Sci. 16:300-309.

Mols, M., and Abee, T. 2011. Primary and secondary oxidative stress in Bacillus. Environ. Microbiol. 13:1387-1394.

Moscatiello, M., Mariani, P., Sanders, D., and Maathuis, F. J. M. 2006 Transcriptional analysis of calcium-dependent and calcium-independent signalling pathways induced by oligogalacturonides. J. Exp. Bot. 57:2847-2865.

Moscatiello, R., Alberghini, S., Squartini, A., Mariani, P., and Navazio, L. 2009. Evidence for calcium-mediated perception of plant symbiotic sig- nals in aequorin-expressing Mesorhizobium loti. BMC Microbiol. 9:206.

Moscatiello, R., Squartini, A., Mariani, P., and Navazio, L. 2010. Flavonoid-induced calcium signalling in Rhizobium leguminosarum bv. viciae. New Phytol. 188:814-823.

Murphy, T. M., Nilsson, A. Y., Roy, I., Harrop, A., Dixon, K., and Keshavarz, T. 2011. Enhanced intracellular $\mathrm{Ca}^{2+}$ concentrations in Escherichia coli and Bacillus subtilis after addition of oligosaccharide elicitors. Biotechnol. Lett. 33:985-991.

Murray, J. D. 2011. Invasion by invitation: Rhizobial infection in legumes. Mol. Plant-Microbe Interact. 24:631-639.

Nanda, A. K., Andrio, E., Daniel Marino, D., Pauly, N., and Dunand, C. 2010. Reactive oxygen species during plant-microorganism early interactions. J. Integr. Plant Biol. 52:195-204.

Navazio, L., Moscatiello, R., Bellincampi, D., Baldan, B., Meggio, F., Brini, M., Bowler, C., and Mariani, P. 2002. The role of calcium in oligogalacturonide-activated signalling in soybean cells. Planta 215:596-605.

Oldroyd, G. E. D., and Robatzek, S. 2011. The broad spectrum of plant associations with other organisms. Curr. Opin. Plant Biol. 14:347-350.

Oldroyd, G. E. D., Murray, J. D., Poole, P. S., and Downie, J. A. 2011. The rules of engagement in the legume-rhizobial symbiosis. Annu. Rev. Genet. 45:119-144.

Panek, H. R., and O'Brian, M. R. 2004. KatG is the primary detoxifier of hydrogen peroxide produced by aerobic metabolism in Bradyrhizobium japonicum. J. Bacteriol. 186:7874-7880.

Peleg-Grossman, S., Volpin, H., and Levine, A. 2007. Root hair curling and Rhizobium infection in Medicago truncatula are mediated by phosphatidylinositide-regulated endocytosis and reactive oxygen species. J. Exp. Bot. 58:1637-1649.

Plazinski, J., and Rolfe, B. G. 1985. Analysis of the pectolytic activity of Rhizobium and Azospirillum strains isolated from Trifolium repens. J. Plant Physiol. 120:181-187.

Ramu, S. K., Peng, H.-M., and Cook, D. R. 2002. Nod factor induction of reactive oxygen species production is correlated with expression of the early nodulin gene ripl in Medicago truncatula. Mol. Plant-Microbe Interact. 15:522-528.

Ridley, B. L., O’Neill, M. A., and Mohnen, D. 2001. Pectins: Structure, biosynthesis, and oligogalacturonide-related signaling. Phytochemistry 57:929-967.

Rigden, D. J., Jedrzejas, M. J., Moroz O. V., and Galperin, M. Y. 2003. Structural diversity of calcium-binding proteins in bacteria: Singlehanded EF-hands? Trends Microbiol. 11:295-297.

Rigden, D. J., Woodhead, D. D., Wong, P. W., and Galperin, M. Y. 2011. New structural and functional contexts of the Dx[DN]xDG linear motif: Insights into evolution of calcium-binding proteins. PLoS One 6:e21507. Published online

Robledo, M., Jiménez-Zurdo, J. I., Velázquez, E., Trujillo, M. E., ZurdoPiñeiro, J. L., Ramírez-Bahena, M. H., Ramos, B., Díaz-Mínguez, J. M., Dazzo, F. B., Martínez-Molina, E., and Mateos, P. F. 2008. Rhizobium cellulase CelC2 is essential for primary symbiotic infection of legume host roots. Proc. Natl. Acad. Sci. U.S.A. 105:7064-7069.

Robledo, M., Jiménez-Zurdo, J. I., Soto M. J., Velázquez, E., Dazzo, F., Martínez-Molina, E., and Mateos, P. F. 2011. Development of functional symbiotic white clover root hairs and nodules requires tightly regulated production of rhizobial cellulase CelC2. Mol. Plant-Microbe Interact. 24:798-807.

Rong, L. J., Carpita, N., Mort, A., and Gelvin, S. 1994. Soluble cell wall compounds from carrot roots induce the picA and $\mathrm{pgl}$ loci of Agrobacterium tumefaciens. Mol. Plant-Microbe Interact. 7:6-14.

Salzwedel, J. L., and Dazzo, F. B. 1993. pSym nod gene influence on elicitation of peroxidase activity from white clover and pea roots by rhizobia and their cell-free supernatants. Mol. Plant-Microbe Interact. 6:127134.

Santos, R., Hérouart, D., Sigaud, S., Touati, D., and Puppo, A. 2001. Oxidative burst in alfalfa-Sinorhizobium meliloti symbiotic interaction. Mol. Plant-Microbe Interact. 14:86-89.

Stael, S., Wurzinger, B., Mair, A., Mehlmer, N., Vothknecht, U, and Teige, M. 2012. Plant organellar calcium signaling: An emerging field. J. Exp. Bot. 63:1525-1542.

Torrecilla, I., Leganés, F., Bonilla, I., and Fernández-Piñas, F. 2004. A calcium signal is involved in heterocyst differentiation in the cyanobacterium Anabaena sp. PCC7120. Microbiology 150:3731-3739.

Torres, M. A. 2010. ROS in biotic interactions. Physiol. Plant. 138:414 429.

Vargas, M. del C., Encarnación, S., Dávalos, A., Reyes-Pérez, A., Mora, Y., García-de los Santos, A., Brom, S., and Mora, J. 2003. Only one catalase, $k a t G$, is detectable in Rhizobium etli, and is encoded along with the regulator OxyR on a plasmid replicon. Microbiology 149:1165-1176.

Vincze, E., and Bowra, S. 2006. Transformation of Rhizobia with broadhost-range plasmids by using a freeze-thaw method. Appl. Environ. Mi- 
crobiol. 72:2290-2293.

Wei, M., Yokoyama, T., Minamisawa, K., Mitsui, H., Itakura, M., Kaneko, T., Tabata, S., Saeki, K., Omori, H., Tajima, S., Uchiumi, T., Abe, M., and Ohwada, T. 2008. Soybean seed extracts preferentially express genomic loci of Bradyrhizobium japonicum in the initial interaction with soybean, Glycine $\max$ (L.) Merr. DNA Res. 15:201-214.

Wen, F., VanEtten, H. D., Tsaprailis, G., and Hawes, M. C. 2007. Extracellular proteins in pea root tip and border cell exudates. Plant Physiol. 143:773-783.

Xie, F., Murray, J. D., Kim, J., Heckmann, A. B., Edwards, A., Oldroyd, G. E. D., and Downie, J. A. 2012. Legume pectate lyase required for root infection by rhizobia. Proc. Natl. Acad. Sci. U.S.A. 109:633-638.

Young, J. P. W., Downer, H. L., and Eardly, B. D. 1991. Phylogeny of the phototrophic rhizobium strain BTAil by polymerase chain reaction- based sequencing of a 16S rRNA gene segment. J. Bacteriol. 173:22712277.

Young, J. P. W., Crossman, L. C., Johnston, A. W. B., Thomson, N. R., Ghazoui, Z. F., Hull, K. H., Wexler, M., Curson, A. R. J., Todd, J. D., Poole, P. S., Mauchline, T. H., East, A. K., Quail, M. A., Churcher, C., Arrowsmith, C., Cherevach, I., Chillingworth, T., Clarke, K., Cronin, A., Davis, P., Fraser, A., Hance, Z., Hauser, H., Jagels, K., Moule, S., Mungall, K., Norbertczak, H., Rabbinowitsch, E., Sanders, M. Simmonds, M., Whitehead, S., and Parkhill, J. 2006. The genome of Rhizobium leguminosarum has recognizable core and accessory components. Genome Biol. 7:R34.

Zhou, Y., Yang, W., Kirberger, M., Lee, H. W., Ayalasomayajula, G., and Yang, J. J. 2006. Prediction of EF-hand calcium-binding proteins and analysis of bacterial EF-hand proteins. Proteins 65:643-655. 